\title{
The irrational and the shift of human boundaries in contemporary novels by Castillon, Martinez and NDiaye
}

\author{
Sophie Guignard (Dept of Romance Studies and Classics, with \\ funding from the Swedish Research Council - Stockholm University, \\ Sweden)
}

\begin{abstract}
The infiltration of magical, marvellous and fantastic features in novels which have a realist anchoring is a remarkable trend in contemporary literature by women writers in French. In order to reveal the issues conveyed by such an imagery built on various literary traditions, I examine the representations of the irrational in recent novels by three authors: Eux (2014) and Les Pêchers (2015) by Claire Castillon, Du Domaine des murmures (2011) and La Terre qui penche (2015) by Carole Martinez and Ladivine (2013) by Marie NDiaye. I use the term "irrational" as a comprehensive notion referring to the fantastic and supernatural elements in the novels, including altered perceptions, paranormal and strange occurences, metamorphosis, staging of an alter ego, monstrosity and animality in human beings, life-after-death issues, emphasised relations to nature, and other phenomena and states that can not be explained by logic. Formulations of the irrational theme exploit a literary patrimony, related in particular to the traditions of medieval marvellous literature, the fairy tales, fantastic literature, surrealism and fantastic realism. I find that the irrational articulates a shift in human spatiotemporality towards vegetal states, animality or monstrosity, and initiates an altered approach to the world. A displaced sense of reality stemming from irrational phenomena and perceptions leads to a dislocation of human consciousness which is performed through the narrative voices. The framework for the analysis consists of a feminist and posthumanist conceptualisation which involves the notions of 'performativity' and 'traces' developed by Butler and Derrida.
\end{abstract}

Keywords: French novels, contemporary women writers, irrational, fantastic, irr(el)ational

This article investigates the irrational motive which is driven through the narrative voices in recent novels by Claire Castillon ${ }^{1}$, Carole Martinez ${ }^{2}$ and Marie NDiaye ${ }^{3}$. The novels have been chosen carefully from works by present day French and francophone women writers who use the cultural heritage of French speaking western european society, although they may

\footnotetext{
${ }^{1}$ Claire Castillon, Eux, Paris: l'Olivier, 2014.

—, Les Pêchers, Paris: l'Olivier, 2015.

${ }^{2}$ Carole Martinez, Du Domaine des Murmures, Paris: Gallimard, 2011.

_, La Terre qui penche, Paris: Gallimard, 2015.

${ }^{3}$ Marie NDiaye, Ladivine, Paris: Gallimard, 2013.
} 
also have different local and specific sociocultural experiences and origins. The authors all have a high-profile reputation, have all received prizes arwarded by the French literary institutions, and enjoy a wide international audience. This makes them representative of existing trends in today's society. The selected authors deal with the various approaches of the irrational and exploit mixed features from greco-latin mythology, from the marvellous and from the fantastic genre. Moreover, they all manifest a struggle with both language and cultural references, which raises issues about fiction and reality and about the socio-historical patrimony. They verbalize existential, relational and societal questions through several narrative voices with extraordinary perceptions of reality. For those reasons, they are well suited to the exploration of the tension between rationality and irrationality displayed in the narrative. All the novels are current having been published since 2011 and their authors selected within a 10 year age span. They also provide socio-cultural diversity. These factors give a balance and coherence to the study.

I will first present the corpus and define the concept of irrationality. Thereupon, I will briefly address the literary filiation of the irrational theme and, lastly, I will highlight some examples of a shift of human boundaries found in the works from the standpoint of a posthumanist conceptualisation. Further dealing with the question of the world experiences and conceptions mediated through the narrative voices, I will introduce the idea that the notion of the irrational implies a cultural positioning.

The stories in Carole Martinez' novels take place in the Middle Ages (in 1187 and 1361 respectively). They display supernatural phenomena and connect with the literary origin of the marvellous, as Claude Lecouteux locates it ${ }^{4}$. However, these novels do not place the action in a fairy world, but bring a fictional perspective on the history of our real world. Furthermore, although medieval popular beliefs feed the stories, the protagonists manifest acertain lucidity towards the superstitions on which the narratives are built, particularly in $D u$ Domaine des Murmures where the heroine manipulates popular naivety and religiosity to protect herself - and her son - from the consequences of a rape she suffered. The novel tells the story of Esclarmonde, who was condemned by her father, after refusing a marriage, to be immured in a tiny room adjacent to the chapel of the Castle. The morning preceding her confinement, she was raped (the reader learns later that her father was the perpetrator of the crime) and she gives birth to a son in captivity. To protect herself and her son Elzéar, whose name means 'relief from God', she maintains the rumour of a miracle and becomes the object of a cult with the power of moving pilgrims, who come to visit her through the bars of her prison. During the first years of Elzéar's life, Esclarmonde has a symbiotic relationship with him, while her visions bring her on the scene of the wars and crusades conducted by her father. The novel explores different facets of the irrational through Esclarmonde's perceptions and intertwines religious and mystical beliefs with popular superstitions, but also pragmatic strategies to survive in this environment.

The action of La Terre qui penche also takes place in the Middle Age. The narrative is split into the two voices of the double ghost of Blanche, who died at the age of 12. The 'little girl' and the 'old soul' alternate their narrative accounts from the grave that they share, and they each offer a supernatural perspective of Blanche's existence.

In the novels by Claire Castillon and Marie NDiaye, the stories take place in our time. They are built around relationships, family and intergenerational situations. In Eux, the

\footnotetext{
${ }^{4}$ Claude Lecouteux, Au-delà du Merveilleux. Des croyances au Moyen Age, Paris: Presses de l'Université ParisSorbonne, 1995.
} 
protagonist is pregnant and hears the voices of 'the ancestors' through the walls. Les Pêchers presents the stories of three female characters in a blended family and Ladivine highlights the transgenerational maternal link within a family history.

These novels involve strange phenomena, disturbed perceptions, crossing psychological and physical boundaries between human beings, metamorphosis, including the transformation of woman into animal. This latter theme is common in fantastic literature, and was especially developed by Rachilde in the decadent novel entitled L'Animale in 1892. It is more recently found in previous novels by Marie NDiaye and Claire Castillon and, of course, in the famous novel Truismes published in 1996 by Marie Darrieussecq. Women's metamorphosis and their particular relationship to the animal are also themes developed in Carole Martinez' novels. The propensity of the characters to escape from their women-bodies and the epiphany in a conversion to an animal now seems to be back as a major theme in these novels. These tendencies participate in self-transcendence in order to explore the realms beyond one's physical existence. The porosity between human beings, especially in the intergenerational relationship, is also a striking feature of the novels' female characters.

To introduce the concept of the irrational, which is at the heart of the present study, Thomas Ferenczi evokes a loss of faith inherited from the time of the World Wars that shook the certainties and values upheld by our social institutions ${ }^{5}$. The crisis of confidence even affected science, which is based on the triumph of reason. However, as pointed out by Roger Lesgards, the irrational has two faces: one expresses a lack which appears as a negative value compared to reason; the other one emerges as a resistance to the order of rationality, which would enable us to grasp what is out of reach of the reason ${ }^{6}$. Among the features of the irrational, it is worth noting that it does not comply with the (rational) principle of noncontradiction and, according to the philosopher Thérèse Delpech, it has the ability to raise and extend the mind by pushing the boundaries of the psychical world, and by accepting, either for a short time while waiting for an explanation, or more definitively, what the reason does not understand ${ }^{7}$.

Starting from this reflection, we may also notice that fiction is characterised by a release from the logical constraints of reality. This in turn allows for the exploration of the aporetic and irrational modalities contained in the experiences of the world, within a preserved coherence which is that of the fictional narrative.

The term 'irrational' will be considered here, both as all phenomena and thoughts in the novels that are beyond the logic of rational reasoning on which the laws of reality rest, and as a category gathering different literary traditions which have in common to deploy such features. As irrational phenomena, I include the fantastic, the supernatural, the strange, distorted perceptions, hallucinations, paranormal phenomena, metamorphoses, the staging of split personalities, monstrosity, animality in humans, involvement in a world beyond death, exaltation and exacerbated emotions, for example in relation to nature, as well as all the phenomena and states that cannot be explained logically.

Defined in this way, the irrational is found in different literary traditions, of which I will here mention those that I may rely on to give a historical perspective to my specific

\footnotetext{
${ }^{5}$ Thomas Ferenczi, Le Monde. L'irrationnel, menace ou nécessité ? Paris: Seuil, 1998, p. 7.

${ }^{6}$ Roger Lesgards, "Ralentir, mot piégé", in Ferenczi, Thomas (dir.), Le Monde. L'irrationnel, menace ou nécessité ? Paris: Seuil, 1998, p. 16.

${ }^{7}$ Thérèse Delpech, L'Appel de l'ombre. Puissance de l'irrationnel, Paris: Grasset, 2010, p. 167.
} 
corpus: the marvellous, the mystical, fantastic literature, surrealism, magical realism and the strange.

Fantastic literature has been the subject of many theorisations. Among these, the one of Tristan Todorov ${ }^{8}$ provides definitions and categorisation tools, and is still a reference today, however been criticised, especially by researchers such as Denis Mellier, Roger Bozzetto and Arnaud Huftier ${ }^{9}$, who accuse Todorov of overlooking socio-historical aspects and cultural contexts. These researchers believe that fantastic literature is not a static but an evolutionary genre. The idea of a wider socio-cultural implication of fantastic literature has been advanced by Joel Malrieu, who has shown how fantastic literature in the 19th century is linked to a crisis of social values and expresses a collective intellectual destabilisation ${ }^{10}$. The researcher Irène Bessière also considers fantastic narrative as a counterculture ${ }^{11}$.

It is worth mentioning that many works studying the literary genres of the marvellous, surrealism and magic realism, cite the novels of Marie Ndiaye in the context of magical realism or of fantastic realism and the strange. Besides, several studies highlight the presence of a marvellous component in the surrealist production ${ }^{12}$. In other words, we have a proliferation of approaches and categorisations, with an overlap and a fairly porous demarcation between established genres, forming a patrimony - I would write 'matrimony' if the word had not acquired a different meaning from its masculine form - in which the authors have been able to draw from various sources of inspiration for the treatment of the irrational theme.

The novels discussed in this article have in common that their plots all develop the issue of crime, whether it be rape, confinement and deprivation of liberty, incest, or murder. Traumatic experiences can be observed in all these novels, involving the protagonists and the narrative in an 'irrational' universe. The process that not only enables the protagonists to reach beyond their sexual and social restrictions, but also, in an even wider perspective, questions and transgresses the concept of humanity, can be displayed by using the idea of a performative construction of gender identity, body, and reality. The concept of performativity is described by Judith Butler who offers a gender theory which is inspired and developed from the works of John Langshaw Austin ${ }^{13}$ and John Searle ${ }^{14}$ about language and social construction. Butler defines the notion of performativity as the dimension of the speech that has the ability to produce what it designates ${ }^{15}$. Considering the performative function which is exerted through the narrative voice ${ }^{16}$ will reveal how the narrative development of the

\footnotetext{
${ }^{8}$ Tzvetan Todorov, Introduction à la littérature fantastique, Paris: Seuil, 1970.

${ }^{9}$ Roger Bozzetto and Arnaud Huftier, Frontières du fantastique : approches de l'impensable en littérature, Valenciennes: Presses Universitaires de Valenciennes, 2004.

${ }^{10}$ Joël Malrieu, Le Fantastique, Paris: Hachette, 1992. This work was written as an answer to Charles Nodier's manifest "Du fantastique en littérature" published in 1830 in Revue de Paris.

${ }^{11}$ Irène Bessière, Le Récit fantastique, la poétique de l'incertain, Paris: Larousse, 1974.

${ }^{12}$ See for example Tania Collani, Le Merveilleux dans la prose surréaliste européenne, Paris: Hermann, 2011 and Ilene Susan Fort, \& Tere Arcq, (ed.), Au pays des merveilles. Les aventures surréalistes des femmes artistes au Mexique et aux États-Unis, translated by Jean-François Allain, Los Angeles, Munich, Londres, New York: Los Angeles County Museum of Art, 2012.

${ }^{13}$ John Langshaw Austin, How to do things with words, Oxford University Press, 2 nd ed., 1975.

${ }^{14}$ John Searle, The Construction of social reality, New York: The Free Press, 1995.

15 Judith Butler, "Gender as Performance" in Radical Philosophy, 64, summer 1994.

${ }^{16}$ The 'narrative voice' is a concept developed by Gérard Genette in "Discours du récit: essai de méthode", Figures III, Paris, Seuil, 1972 and in Nouveau discours du récit, Paris: Seuil, 1983.
} 
irrational motive in the novels (dis)articulates discursive dynamics concerning the characters and their relationships.

I will now give some examples of strategies in the novels that reflect the reconfiguration of an experience of the world, and the issues emerging through the narrative development of the irrational theme. In the following excerpt, one of the protagonists of Les Pêchers by Claire Castillon embraces the traumatic experience so that she herself becomes part of the materiality of objects which are connected to the trauma, to such an extent that she identifies with the will of men, who are designated as 'the danger:

Je me suis confondue avec le tapis quand le danger voulait du sauvage, confondue avec le
mur quand le danger avait de bons muscles et confondue avec les draps quand le danger
avait sommeil. Je me suis confondue avec le danger jusqu'à ne plus le reconnaître ${ }^{17}$.

You could say that she performs at the same time her objectification in the sexual relationship and in the desires of the man from whom she does not any longer distinguish herself.

In Ladivine, Marie NDiaye's characters develop different transgressions of human features. The vegetal quality is described through the image of a dark flower ('fleur obscure') shared by Malinka and her mother. The dark side of this flower evokes the idea of a trauma experienced by the protagonists, which is related to the abandonment and rejection that they have endured. In the novel, the vagueness of the gaze is a recurring quality of the characters. The boundaries between human beings and their environment are blurred, allowing feelings to become autonomous, detached from the person, so that they can choose the place where they will express themselves.

Thus, during the episode preceding the separation between Clarisse and Richard Rivière after he announced his departure, the house had heard and understood before Clarisse - alias Malinka - what Richard Rivière had said ${ }^{18}$. The painful event causes Clarisse to experience a symbiotic merger with stone, as well as vegetal and animal states. As evidenced by the following excerpt, Clarisse's emotional distress is displaced and maintained within her flesh like irrevocable words between the walls:

Sa chair dense et ferme s'était refermée sur la douleur comme les murs de la maison sur les paroles irrévocables ${ }^{19}$.

Here, we see how the pain is materialised and produces a petrification of the body. The petrification of a body-container conveys an experience of depersonalisation, such as it has been encountered in previous novels by Marie NDiaye and Claire Castillon, or, for instance, in novels by George Sand ${ }^{20}$. Depersonalisation is a state caracterised by disturbed perceptions of reality and self, sensory disruption and denial of body sensations. The narrator establishes a bond of significance between spoken words and the inscription of the affects in

\footnotetext{
${ }^{17}$ Tamara speaking in Les Pêchers. The main protagonists are: Tamara, Claude, Aimée, Quick and Ester.

${ }_{18}^{18}$ Marie NDiaye, Ladivine, op. cit., p. 101.

${ }^{19}$ Ibid., p. 104.

${ }^{20}$ See Mon cour à l'étroit by Marie NDiaye, Vous parler d'elle by Claire Castillon and Lélia by George Sand. I develop the idea of a body-container in my doctoral thesis Le cour, l'âme et le corps. Expressions de l'intime féminin dans sept romans du XIX $X^{e}$ siècle et de l'extrême contemporain, Uppsala: Acta Universitatis Upsaliensis, 2015.
} 
the body thus revealing an alienating discourse which can be related to mecanisms of objectification of woman body, and repression of feelings and sexuality.

Along similar lines, we find a description of a symbiosis with a tree which also shows a derealization:

Voilà que son regard se perdait dans l'opulente frondaison du marronnier et que, sentant sur sa main les lèvres râpeuses de Richard Rivière, elle crut que le tronc lui-même baisait sa paume, que l'arbre tout entier voulait faire son propre salut après lui avoir causé, pour quelque raison, une souffrance telle qu'elle n'en réchapperait pas [...] elle sentait maintenant s'ouvrir en elle le chemin d'une douleur prodigieuse mais elle en ignorait l'origine et songeait avec une lente surprise que le marronnier qui poussait péniblement ses racines sous le goudron de la place, si c'était bien lui qui cherchait à se racheter en soufflant sur sa main une haleine sèche, n'avait guère les moyens de l'affliger, ce malheureux arbre au pied jonché d'ordures ${ }^{21}$.

The protagonist here shares her pain with the tree which suffers a condition of oppression imposed by humans. The community of suffering that binds the protagonist to her environment is also reflected in the theme of animal symbiosis, carried out by means of a dog: "son corps lui semblait être un vieux chien qu' on ne châtierait jamais assez pour avoir, par exemple, dévoré un petit enfant ${ }^{22, "}$.

As in the previous quote, these words evoke not only a shift of individual consciousness, which is projected on the environment, but also the idea of a fault to atone for. It is a vision that is deterministic and even rather fatalistic, where the individual is driven by her past actions to be no more than a cog in a reality that extends beyond her scope. That is what Ladivine Sylla expresses here about her relationship with her daughter:

elle en était venu à croire qu'elles étaient prises toutes les deux dans les liens serrés d'un même sortilège que Malinka pas plus qu'elle-même ne pouvait dénouer, qu'elles étaient châtiées l'une comme l'autre aussi cruellement, aussi injustement ${ }^{23}$.

The idea of a spell is typical of the imaginary of fairy tales. The expiation will be achieved through murder, by and beyond the death of Clarisse. It should be noted that, in this novel, the relationship between the characters is also woven from a matriarchal legacy of the name, since both the grandmother and her granddaughter are called Ladivine. The name - and more particularly the first name - plays an important role in the construction of identity, relationships, and the relative autonomy of the characters, and sustains a bond that transcends their physical condition.

Carole Martinez, in La Terre qui penche, offers, for her part, a vision of the individual who is transcended and extended through writing, and who denies the reality of physical death:

Je suis une femme à présent, une femme qui sait lire, je peux écrire mon nom, je peux écrire en mon nom. Je briserai les badines sur les côtes de ceux qui m'en menaceront, je ferai la nique au diable et je mordrai les enfants qui jettent des cailloux aux pendus. [...] Quitte ton trou, vieille âme, nous ne sommes pas morte ici! Tu t'es égarée en enfance. Il

\footnotetext{
${ }^{21}$ Marie NDiaye, Ladivine, op. cit., p. 103.

${ }^{22}$ Ibid., p. 111.

${ }^{23}$ Ibid., p. 154.
} 
est temps pour toi de t'en aller à ton tour. Cesse de ressasser et de hanter ces lieux, il faut partir, vieille âme! $!^{24}$

By learning to write, starting with her own name, Blanche wins her freedom and can leave the murky world of ghosts associated with childhood. The potentiality of power contained in this experience is reminiscent of Lacan's thoughts about the name of the father, figure of the law ${ }^{25}$. The protagonist appropriates her name and language by learning to write her name. However, this name, Blanche, has many connotations, and suggests the idea of a blank page.

The connection between the physical being and its metaphysical dimension, as well as between speech and thought, which is characteristic of the human, is suggested and described here:

Je dis 'nous' comme si je participais toujours à ce grand cirque des vivants. Mais ai-je encore quelque chose d'humain, moi qui ne suis rien qu'un pet d'air?

Sans doute, puisque ça parle en moi et que ma pensée se refuse au néant ${ }^{26}$.

The idea of a "circus of the living" associates human life to a show, a performance which would be the mode of human condition. The protagonist assumes the performative character of her existence which acquires meaning through thought and speech.

These examples show that the irrational contributes to expanding and moving beyond human perspective. It is not only a movement of the individual conscience in space, towards mineral, vegetal and animal environment, but also an intergenerational temporal displacement.

Like in Ladivine, where a dog establishes a sort of generational connection and appears to the protagonist as the embodiment of her own mother, the wolf and the dog stand for this generational legacy in Castillon's novels and suggest, through a wild and obscure side as well as the idea of domestication, that the protagonist's lineage belongs to the animal:

La situation empire. Dans les murs, la fréquence augmente. On m'interrompt dès que je cogite. Les héréditaires m'interdisent de penser, m'interdisent de sortir. Je pars dans la salle de bain. Les héréditaires rient là-bas aussi, et j'entends un bruit de fesses. [...] La famille devient pornographique. Les héréditaires m'attendent derrière les toilettes, dans le mur, toujours dans le mur [...].

Muette, je dessine un cri. Assise sur la cuvette, je deviens une auréole. Si je me regarde de profil, apparaît une femme muselée. Je la vois dans la glace, c'est moi et pas moi. Je finis par avoir peur. Elle jappe ${ }^{27}$.

The protagonist blends her silent cry with the voices of the ascendants and with the sound of the unborn daughter that she is still carrying inside her. The fact that the infant is a daughter also deserves to be noticed, as it would seem that the female characters in the novels are especially permeable and affected by that dimension of hereditary transmission which is performed through irrational phenomena, as we can judge here: "J'ai des voix qui me

\footnotetext{
${ }^{24}$ Carole Martinez, La Terre qui penche, p. 358-359.

25 Jacques Lacan, Des noms-du-père, Paris: Seuil, 2005.

${ }^{26}$ Carole Martinez, La Terre qui penche, op. cit., p. 40.

${ }^{27}$ Claire Castillon, Eux, p. 98.
} 
traversent, parfois la mienne et celle de ma fille se percutent. Le gong est métallique. Sous mon crâne, tout explose $\mathrm{e}^{28,}$.

We can see through the cited excerpts that the issue of a legacy is problematic for the experience of the female characters because it occurs in confrontation with individual identity construction, in obscure ways, such as petrification, harassment by ghosts, muzzling and animal metamorphosis. It is worth noticing that the narrative voice, in these novels, is not built in opposition of self to others and to the world, in a relational duality, but by a process of invasion, transformation, and metamorphosis. In this regard, Margaret-Anne Hutton has expressed the idea that the fantastic elements in French or francophone literature may be a manifestation of 'a post-national' anxiety, in a context of globalised contemporaneity and complex socio-cultural identities ${ }^{29}$. We can see from the previous quotations that the irrational features in the novels can be associated with anxiety and struggle with socio-cultural identity. The notion of the 'uncanny' used by Shirley Jordan ${ }^{30}$, Margaret-Anne Hutton and Gill Rye ${ }^{31}$, among others, offers an appropriate perspective in order to describe memories, spatial and temporal benchmarks witnessing the protagonists' trauma, emotional conditions, relationships, and signs of altered perceptions.

It also seems that the protagonists tend to withdraw from social involvement, something which can be judged as a failure in the social and relational field of human existence. Giving up their human shell to dwell in an animal or ghostly shape allows them to reach a form of freedom and a stature to influence human beings to which they are related, but it implies an abnegation of their lives and the breakdown of communication according to social patterns, occurring as a rejection and a transcendence of the human condition. For reasons which differ depending on the novels, the inability to establish acceptable relationships and an appropriate social position leads the protagonists to a self-deletion and a withdrawal from the social order. This position contrasts with the efforts of asserting the rights, the bodily integrity and the empowerment that has characterised the feminist momentum and continues to characterise the socio-political scene of our time. This trend in these literary fictions indicates a movement, initiated by women themselves, towards renunciation and loss of sovereignty in the world. I will call this process 'irr(el)ational', a concept that I will discuss more thoroughly in a forthcoming study. The 'irr(el)ational' can be described as a transgression and instability of the physical and psychic limits of the human, a deplacement which impacts the intersubjective dimensions and defy an anthropocentric view of the world. Such alteration is embraced by posthumanist theorists like Ihab Hassan who, in his article "Prometheus as Performer: Toward a Posthumanist Culture", asserts that: "We need first to understand that the human form - including human desire and all its external representations - may be changing radically, and thus re-envisioned ${ }^{32}$ \%. The fluctuation of individual identity that is observed in the novels and the exploration of a performative construction, mark an ambiguity about one's physical limits and sense of self and raise

\footnotetext{
${ }^{28}$ Ibid., p. 141.

${ }^{29}$ Margaret-Anne Hutton, Redefining the Real. The Fantastic in Contemporary French and Francophone Women's Writing, Oxford: Peter Lang, 2009.

${ }^{30}$ Shirley Ann Jordan, Contemporary French Women's Writing, Bern: Peter Lang AG, European Publishers, 2004.

31 Amaleena Damlé \& Gill Rye (dir.), Women's writing in twenty-first-century France. Life as literature, Cardiff: University of Wales Press, 2013.

${ }^{32}$ Ihab HASSAN, "Prometheus as Performer: Toward a Posthumanist Culture", The Georgia Review 4, 1977, p. 843 .
} 
phenomenological considerations such as the controversy between existential and posthumanist philosophers about consciousness and the place of humans in the world. In the novels, the erasure of the subject induced by denial, separation, death, crime or metamorphosis, results in a 'trace' in the sense of 'animal traces', a concept developed by Jacques Derrida as well as Hélène Cixous and later exposed by Anne E. Berger ${ }^{33}$. The issues concerning margins, borders, boundaries and threshold worlds, raised by the writing of the irrational and the resulting 'traces' involve the notion of withdrawal as it has been discussed by Derrida - withdrawal of identity, of presence - in a dialectic where self-erasure confronts the established trace in the irreducible absence of the other, and where the name refers to the unspeakable. The 'traces' corroborate an altered conception of the world, where animals and nature play a prominent part. Setting animal 'traces', imprints in nature, engraved letters and mementos in the foreground, participates in a shifted conception of human reality.

It is thus a posthumanist vision which is proposed in the novels, and there is reason to reflect upon what it reveals about the mirrored human relations and, more specifically, about women's social position, because this configuration is elaborated by women and highlights the experiences of female characters.

\section{References}

\section{Corpus}

CASTILLON, Claire, Eux, Paris: l'Olivier, 2014.

—, Les Pêchers, Paris: l'Olivier, 2015.

MARTINEZ, Carole, Du Domaine des Murmures, Paris: Gallimard, 2011.

—, La Terre qui penche, Paris: Gallimard, 2015.

NDIAYE, Marie, Ladivine, Paris: Gallimard, 2013.

\section{Reference books}

AUSTIN, John Langshaw, How to do things with words, Oxford University Press, 2nd ed., 1975.

BERGER, Anne Emmanuelle, Demenageries. Thinking (of) Animals after Derrida, Amsterdam, New York: Rodopi, 2011.

BESSIÈRE, Irène, Le Récit fantastique, la poétique de l'incertain, Paris: Larousse, 1974.

BOZZETTO, Roger and HUFTIER, Arnaud, Frontières du fantastique: approches de l'impensable en littérature, Valenciennes: Presses Universitaires de Valenciennes, 2004.

BUTLER, Judith, "Gender as Performance” in Radical Philosophy, 64, summer 1994.

COLLANI, Tania, Le Merveilleux dans la prose surréaliste européenne, Paris: Hermann, 2011.

\footnotetext{
33 Anne Emmanuelle Berger, Demenageries. Thinking (of) Animals after Derrida, Amsterdam, New York: Rodopi, 2011.
} 
DAMLÉ, Amaleena \& RYE, Gill (dir.), Women's writing in twenty-first-century France. Life as literature, Cardiff: University of Wales Press, 2013.

DERRIDA, Jacques, La Dissémination, Paris: Seuil, 1972.

—, Psyché: inventions de l'autre, Paris: Galilée, 2003.

—, L'Animal que donc je suis, Paris: Galilée, 2006.

_, Séminaire La bête et le souverain. Vol. 2, (2002-2003), Paris: Galilée, 2010.

DESBLACHE, Lucile, La plume des bêtes. Les animaux dans le roman, Paris: L'Harmattan, 2011.

-, (dir.) Hybrides et monstres: transgressions et promesses des cultures contemporaines, Dijon: Éditions universitaires de Dijon, 2012.

DELPECH, Thérèse, L'Appel de l'ombre. Puissance de l'irrationnel, Paris: Grasset \& Fasquelle, 2010.

FERENCZI, Thomas (dir.), Le Monde. L'irrationnel, menace ou nécessité? Paris: Seuil, 1998. GENETTE, Gérard, "Discours du récit: essai de méthode", Figures III, Paris, Seuil, 1972.

-, Nouveau discours du récit, Paris: Seuil, 1983.

GUIGNARD, Sophie, Le cæur, l'âme et le corps. Expressions de l'intime féminin dans sept romans $d u X I X^{e}$ siècle et de l'extrême contemporain, Uppsala: Acta Universitatis Upsaliensis, 2015.

HARAWAY, Donna, The Companion Species Manifesto: Dogs, People, and Significant Otherness, Chicago: Prickly Paradigm Press. 2003.

—, When species meet, Minneapolis: University of Minnesota Press, 2007.

HASSAN, Ihab, "Prometheus as Performer: Toward a Posthumanist Culture", The Georgia Review 4, 1977.

HUTTON, Margaret-Anne, Redefining the Real. The Fantastic in Contemporary French and Francophone Women's Writing, Oxford: Peter Lang, 2009.

JORDAN, Shirley Ann, Contemporary French Women's Writing, Bern: Peter Lang AG, European Publishers, 2004.

LACAN, Jacques, Des noms-du-père, Paris: Seuil, 2005.

LE GOFF, Jacques, Un autre Moyen Âge, Paris: Gallimard, 1999.

LECOUTEUX, Claude, Au-delà du Merveilleux. Des croyances au Moyen Âge, Paris: Presses de l'Université Paris-Sorbonne, 1995.

LESGARDS, Roger, "Ralentir, mot piégé", in Ferenczi, Thomas (dir.), Le Monde. L'irrationnel, menace ou nécessité? Paris: Seuil, 1998.

MALRIEU, Joël, Le Fantastique, Paris: Hachette, 1992.

RYE, Gill et Worton, Michael (ed. by), Women's writing in contemporary France, Manchester and New York: Manchester University Press, 2002.

SEARLE John R., The Construction of social reality, New York: The Free Press, 1995.

TODOROV, Tzvetan, Introduction à la littérature fantastique, Paris: Seuil, 1970.

—, Théories du symbole, Paris: Seuil, 1977.

_, Poétique de la prose, Paris: Seuil, 1978. 